\title{
Changes in yeast diversity and volatile flavor compounds during fermentation of mugwort sugar extracts
}

\author{
Su Young Hong ${ }^{1}$, Woe Ja Jeong ${ }^{2}$, Hee Yul Lee ${ }^{2}$, Jin Hwan Lee ${ }^{3}$, Chun Eun Hwang ${ }^{2}$, \\ $\mathrm{Su}$ Cheol $\mathrm{Kim}^{2}$, Ok Soo $\mathrm{Joo}^{2}$, Kye Man $\mathrm{Cho}^{2 *}$ \\ ${ }^{1}$ Food Science Research Institute, Kolmar BNH Inc., Sejong 30003, Korea \\ ${ }^{2}$ Department of Food Science, Gyeongnam National University of Science and Technology, Jinju 52725, Korea \\ ${ }^{3}$ Division of Research Development and Education, National Institute of Chemical Safety (NICS), \\ Ministry of Environment, Daejeon 34111, Korea
}

\section{쑥 당-추출액의 발효 중 효모 다양성과 향기성분 변화}

\author{
홍수영 ${ }^{1} \cdot$ 정외자 $^{2} \cdot$ 이희 율 ${ }^{2} \cdot$ 이진환 $^{3} \cdot$ 황정 은 $^{2} \cdot$ 김수철 $^{2} \cdot$ 주옥수 $^{2} \cdot$ 조계만 ${ }^{2 *}$ \\ ${ }^{1}$ 콜마비앤에이치(주) 식품과학연구소, ${ }^{2}$ 경남과학기술대학교 식품과학부, ${ }^{3}$ 환경부 화학물질안전원
}

\begin{abstract}
In this study, we investigated the changes in physicochemical properties, yeast diversity, and volatile flavor compounds during fermentation of mugwort sugar extracts (FMSE). The $\mathrm{pH}$ and sucrose levels decreased, while the acidity and reducing sugar, fructose, and glucose contents increased during FMSE. Oxalic and succinic acids appeared to be the predominant organic acids in FMSE. Based on 26S rRNA sequencing, a total of 7 different yeast species including Candida lactis-condensi, Hanseniaspora uvarum, Hyphopichia burtonii, Saccharomyces cerevisiae, Saccharomyces paradoxus, Torulaspora delbruechii, and Zygosaccharomyces pseudorouxii were identified in 5 sampling sites. The prevalence of $S$. cerevisiae was highest $(95 \%)$ at 30 days and decreased to $7.5 \%$ at 60 days, whereas the abundance of $C$. lactis-condensi increased from $90 \%$ at 60 days to $100 \%$ at 90 days of fermentation. The major volatile flavor compound, 3-methyl-1-butanol, considerably increased from $65.95 \%$ to $82.98 \%$ after 30 days of fermentation and slightly decreased thereafter. In addition, the levels of benzyl alcohol, phenylethyl alcohol, and 5-hydroxymethyl-2-furancarboxyaldehyde increased to $2.56 \%, 5.48 \%$, and $2.54 \%$, respectively, whereas isopentyl alcohol substantially decreased to $0.12 \%$, at 120 days of fermentation.
\end{abstract}

Key words : Mugwort sugar-extracts, fermentation, 26S rRNA gene, yeast diversity, volatile flavor compounds

\section{서 론}

쑥(Artemisia sp.)은 우리나라에서 자생하고 있는 국화과 (Composition)에 속하는 번식력이 강한 다년생 초본식물로 한국이나 중국, 일본 등 아시아 지역과 유럽 지역 등 전 세계적으로 널리 분포되어 있으며 동양에서 전통 생약으로

*Corresponding author. E-mail : kmcho@gntech.ac.kr Phone : 82-55-751-3272; Fax : 82-55-751-3279

Received 16 August 2018; Revised 9 October 2018; Accepted 29 October 2018.

Copyright (c) The Korean Society of Food Preservation. All rights reserved.
널리 사용되어 왔다 $(1,2)$. 특히, 쑥은 만성위장병, 하복 부통, 천식, 구충, 악취제거에 효과가 알려져 있으며 쑥 추출물은 혈당량 저하, 체중감소 방지, 혈중지질 저하, 고지혈증과 당뇨를 개선시킨다고 보고되어 있다 $(3,4)$.

지난 십 오년 동안 분자유전학기술의 발달로 환경 내 미생물 다양성에 대한 정보는 증가하고 있다. 분자유전학 기술은 다양한 환경 및 식품생태계에 관련된 미생물 검출, 식별 및 특성화를 위한 뛰어난 방법으로 알려져 있다. 식품 내에서 미생물의 다양성은 원료, 발효 방식 및 숙성 과정뿐 만 아니라 식품 내에서 미생물이 환경적인 스트레스로부터 자신의 방어를 위해 다양하게 변화한다. 이런 점에서 발효 식품의 다양한 환경적 요인과 미생물 공동체들 사이의 상관 
관계를 파악하기 위해서는 상세한 연구가 필요하다 $(5,6)$. 한편 효모는 단세포 진균이며 진균계의 자낭균류 및 담자균 류 문에 속하는 진핵생물이며 동·식물을 원료로 이용하여 만들어진 장류, 당절임, 김치, 식초, 알코올류 등 많은 발효 식품에서 존재한다(5). $26 \mathrm{~S} \mathrm{rRNA}$ 의 약 $600-650 \mathrm{bp}$ 의 D1/D2 domain 발견되어 지금까지 이들 D1/D2 염기서열분석을 통하여 효모의 동정과 분류에 사용되고 있다(7).

발효는 유산균과 효모 등의 미생물 작용에 의해 유기화 합물이 분해되면서 알코올, 유기산, 탄산가스 등의 분해산 물을 생성하여 식품의 저장성 증가 및 풍미 등의 품질 특성 과 항산화 활성 등의 생리활성을 강화하는 식품가공 공정이 다(8-10). 과실주 및 당 절임과 같은 주류 또는 엑기스 제품 은 효모 발효를 통해 제조되는 가장 대표적인 제품이며 이와 관련된 연구는 널리 알려져 있다(10). 효모를 이용한 발효 방식은 발효 과정 중에 효모 작용에 의해 설탕과 같은 이당류가 분해되고 포도당, 과당 등의 단당류가 생성되고 이 외에도 알코올, 유기산, 각종 향기성분이 생성되어 과실 주 혹은 당 절임 식품의 품질에 영향을 미친다(9).

식물 당-추출발효액은 과일, 채소, 약초류, 해조류 등의 식용작물을 압착 또는 설탕 $\left(55{ }^{\circ} \mathrm{Brix}\right.$ 이상 $)$ 의 삼투압에 의해 얻은 추출물을 자체발효 또는 유산균이나 효모균 등으로 발효시켜 식용에 적합하도록 가공한 것이다 $(5,11,12)$. 본 연구에서는 식용 및 약용으로 널리 사용되고 있는 쑥을 이용하여 쑥 당-추출액을 제조하고 발효 기간 중 이화학 적 - 생물학적 특성, 효모 다양성, 향기성분 변화를 조사하 여 다양한 식물추출발효음료 제조의 기초자료로서 활용하 고자 하였다.

\section{재료 및 방법}

\section{재료, 배지 및 시약}

본 연구에 사용한 쑥은 2014년 5월경 하동지역의 지리산 자락에서 자생한 것을 채취하여 흐르는 물에 3회 세척한 후 물기를 제거하여 사용하였다. 설탕은 시판 백설탕 $(\mathrm{CJ}$ Co., Suwon, Korea)을 진주소재 대형마트에서 구입하여 사 용하였다. 미생물 배양용 배지는 Difco사(Becton Dicknson Co., Sparks, MD, USA) 제품을 사용하였다. 표준 유기산 (acetic acid, lactic acid, citric acid, succinic acid, fumaric acid 및 glutaric acid), 유리당(glucose, fructose 및 sucrose)은 Sigma-Aldrich, Inc.(Merck KGaA, Darmstadt, Germany)에 서 구입하였고 methanol, acetonitrile, water, chloroform, hexane 및 acetone은 Fisher Scientific International, Inc.(Fairlawn, NJ, USA)에서 구입하여 사용하였다. 이외에 기타시약은 필요에 따라 분석용 1 급 또는 특급시약을 구입 하여 사용하였다.

\section{쑥 당-추출액 제조 및 발효}

쑥 $5 \mathrm{~kg}$ 에 백설탕 $5 \mathrm{~kg}$ 을 배합하여 과실주 발효용기에 넣고 상온에서 10 일간 추출한 다음 시중에 판매하는 일반 광목천으로 걸러 추출액만 $10 \mathrm{~L}$ 유리 소재 담금주 용기에 옮긴 후 $20 \pm 3^{\circ} \mathrm{C}$ 에서 120 일간 발효시키면서 30 일 간격으로 시료를 채취하여 실험에 사용하였다.

\section{$\mathrm{pH}$ 및 총산}

$\mathrm{pH}$ 는 추출액 및 발효액 자체를 $\mathrm{pH}$ meter(model 3510 , Jenway, London, UK)를 사용하여 나타난 측정값을 그대로 나타내었으며, 총산은 각각의 시료 $5 \mathrm{~mL}$ 에 증류수 $45 \mathrm{~mL}$ 를 첨가 및 혼합하여 $0.1 \mathrm{~N} \mathrm{NaOH}$ 용액으로 $\mathrm{pH} 8.2 \pm 0.1$ 까지 중화시키는데 소요된 $0.1 \mathrm{~N} \mathrm{NaOH}$ 의 소비 $\mathrm{mL}$ 수를 구하고 아래 식에서와 같이 젖산(lactic acid) 양으로 환산하여 총산 으로 환산하였다.

\section{총산(\%, as lacctic acid) $=0.1 \mathrm{~N} \mathrm{NaOH}$ 소비량 $\times 0.9$}

\section{당도 및 환원당}

당도는 추출액 및 발효액을 일정량 취하고 이를 14,500 $\mathrm{rpm}$ 의 속도로 3 분간 원심분리하여 얻은 상등액을 10 배 희 석하여 굴절 당도계(Sccharometer, W.S.R.O-90, Atago Co., Tokyo, Japan)로 측정하고 ${ }^{\circ} \mathrm{Brix}$ 로 나타내었다. 환원당은 Miller(13)의 DNS법으로 분석하였다. 우선 환원당 측정에 필요한 DNS 시약 제조를 위해 $\mathrm{A}$ 용액(potassium sodium tartarate $300 \mathrm{~g}$ in water)과 B 용액(3,5-DNS solution in $\mathrm{NaOH}$ solution)을 식품공전에 따라 제조하고 이를 $1: 1$ 로 섞은 것을 최종 DNS 시약으로 사용하였다. 즉, 시료를 100 배로 희석 한 후 희석액을 $15 \mathrm{~mL}$ 시험관에 $0.1 \mathrm{~mL}$ 를 분주한 후 DNS 시약을 $1 \mathrm{~mL}$ 첨가하여 $100^{\circ} \mathrm{C}$ 끓는 물에서 10 분 동안 발색시 킨 후 얼음물에서 즉시 냉각하여 분광광도계(Spectronic 2D, Thermo Co., Petaluma, CL, USA)를 사용하여 $570 \mathrm{~nm}$ 에 서 흡광도를 측정하여 검량선과 비교하였다. 검량선 작성 을 위한 표준물질로는 glucose을 사용하였다.

\section{알코올 및 생균수}

알코올 측정은 $500 \mathrm{~mL}$ 플라스크에 시료 $50 \mathrm{~mL}$ 를 취하고 증류수 $100 \mathrm{~mL}$ 를 가하였다. 시료를 비등시켜 증류액이 30 $\mathrm{mL}$ 가 되도록 증류한 다음 시료량이 $50 \mathrm{~mL}$ 가 되도록 증류 수를 가하고 주정계(MT-830, Atago Co., Tokyo, Japan)를 사용하여 알코올량을 측정하였다(14). 효모의 생균수는 Hwang 등(15)의 방법과 마찬가지로 무균적으로 채취한 시 료를 chloramphenicol $(1.5 \mathrm{mg} / \mathrm{mL})$ 함유 potato dextrose(PD) 평 판배지에 도말한 후 $30^{\circ} \mathrm{C}$ 에서 48 시간 배양 후 생성된 집락을 계측하여 $\mathrm{mL}$ 당 colony forming unit $(\mathrm{CFU} / \mathrm{mL})$ 로 표 시하였다. 


\section{유리당 및 유기산}

유리당 및 유기산 분석은 high performance liquid chromatography(HPLC, Agilent 1200 series, Waldbronn, Germany)를 이용하여 분석하였다. 유리당은 시료 $5 \mathrm{~g}$ 에 물 $25 \mathrm{~mL}$ 를 가하여 녹인 후 acetonitrile로 $50 \mathrm{~mL}$ 까지 채웠 다. 이 용액을 sep-pak $\mathrm{NH}_{2}$ column(Waters Co., Myrtle Beach, SC, USA)과 $0.45 \mu \mathrm{m}$ membrane filter(Dismic-25CS, Tokyo, Japan)로 여과한 액을 시험용액으로 사용하였다. 당 분석 column(Polyamine II, Kyoto, Japan)에 시험용액 20 $\mu \mathrm{L}$ 를 주입하고 $35^{\circ} \mathrm{C}$ 에서 이동상 용매[acetonitrile: water $=70: 30(\mathrm{v} / \mathrm{v})]$ 를 $1.0 \mathrm{~mL} / \mathrm{min}$ 속도로 이동시키면서 Reflective Index(RI, Agilent 1200 series, Waldbronn, Germany) 검출기상에서 당을 검출하였다. 유리당은 같은 조건으로 분석한 표준유리당의 검량선과 비교하여 정량하 였다(16).

유기산 분석은 시료에서 HPLC용 물을 가하여 10 배 희석 한 후 $0.2 \mu \mathrm{m}$-membrane filter로 여과하여 유기산 분석을 위한 시료를 준비하였다. 전처리한 시료 $20 \mu \mathrm{L}$ 를 TSKgel ODS-100V column $(4.6 \times 250 \mathrm{~mm}, 5 \mu \mathrm{m}$, Tosoh Co., Tokyo, $\mathrm{Japan})$ 이 장착된 $\mathrm{HPLC}$ 시스템에 주입하고 $30^{\circ} \mathrm{C}$ 에서 이동 상 용매( $0.1 \%$ phosphoric acid)를 $1.0 \mathrm{~mL} / \mathrm{min}$ 속도로 이동시 키면서 UV 검출기(Agilent Co., Forest Hill, Australia) 210 $\mathrm{nm}$ 에서 유기산을 검출하였다. 유기산은 같은 조건으로 분 석한 표준유기산의 검량선과 비교하여 정량하였다(16).

\section{집식배양 및 genomic DNA 분리}

집식배양은 Lee 등(5)에 준하여 수행하였다. 즉, chlorampenicol(1.5 mg/mL)이 함유된 $100 \mathrm{~mL} \mathrm{30 \%} \mathrm{sucrose}$ $\mathrm{PD}$ 액체배지에 쑥당-추출액 및 발효액 $5 \mathrm{~mL}$ 를 접종하여 $28^{\circ} \mathrm{C}$ 에서 $30 \pm 6$ 시간 동안 집식 배양하였다. 집식 배양된 시료 약 $3 \mathrm{~mL}$ 를 $4^{\circ} \mathrm{C}, 13,000 \times \mathrm{g}$ 에서 5 분 동안 원심분리하였 고 모여진 균체는 G-spin Genomic DNA Purification Kit(Intron Co., Suwon, Korea)를 사용하여 genomic DNA를 분리하였다. 분리된 genomic DNA는 라이보좀 RNA(rRNA) 의 $\mathrm{PCR}$ 증폭을 위한 주형으로 사용하였다.

\section{$\mathrm{PCR}$ 증폭}

분리한 genomic DNA를 주형으로 하여 $26 \mathrm{~S}$ rRNA를 증폭 하였다. $26 \mathrm{~S} \mathrm{rRNA}$ 의 단편을 증폭하는데 사용되는 $\mathrm{PCR}$ yeast-specific primer 5'-ACC CGC TGA AYT TAA GCA TAT-3'(3YF/21 mer, forward primer, Saccharomyces cerevisiae rRNA)과 5'-CTC CTT GGT CGT GTT TCA AGA CGG-3'(3YR/25 mer, reverse primer)을 사용하였다(7). 그 뒤에, rRNA는 metagenomic DNA와 Super-Therm DNA 중 합효소(JMR, Side Cup, Kent, UK)를 사용하여 PCR을 증폭 하였다. PCR 반응은 Taq polymerase(2.5 unit) $1 \mu \mathrm{L}$, 3 YF-3YR(10 pmol) primer $3 \mu \mathrm{L}$, 반응 buffer(15 mM MgCl 2 )
$5 \mu \mathrm{L}, 2 \mathrm{mM}$ dNTP $5 \mu \mathrm{L}$, 주형 DNA $5 \mu \mathrm{L}$ 및 증류수 28 $\mu \mathrm{L}$ 로 총 $50 \mu \mathrm{L}$ 를 반응시켰다. 변성은 $94^{\circ} \mathrm{C}$ 에서 30 초, 결합은 $50^{\circ} \mathrm{C}$ 에서 30 초 및 신장은 $72^{\circ} \mathrm{C}$ 에서 90 초 동안 $30 \mathrm{cycle}$ 하고 마지막으로 $72^{\circ} \mathrm{C}$ 에서 10 분 동안 반응시켰다. $\mathrm{PCR}$ 반응이 끝난 후 전기영동하여 $26 \mathrm{~S} \mathrm{rRNA}$ 단편을 확인하고, 효모 26S rRNA 유전자 산물은 PCR Purification Kit(Intron Co.)로 정제하였다.

\section{$26 \mathrm{~S}$ rRNA 라이브러리 구축}

증폭한 효모 rRNA는 pGEM-T easy vector(Promega, Madison, WI, USA)를 사용하여 Escherichia coli DH5a에 클로닝하였다. 재조합 클론은 무작위로 선택하고 재조합 plasmid는 Plasmid DNA Purification Kit(Intron Co.)를 사용 하여 분리하였다. 정제된 plasmid는 $\mathrm{PCR}$ 과 전기영동을 통 해 $26 \mathrm{~S}$ rRNA 크기를 확인하였다.

\section{DNA 염기서열 분석}

염기서열 결정은 PRISM Ready Reaction Dye terminator/ primer cycle sequencing kit(Perkin-Elmer Corp., Norwalk, $\mathrm{CN}, \mathrm{USA}$ )를 사용한 dideoxy chain termination method로 하였다. Sample은 automated DNA sequencer(Applied Biosystems, Foster City, CA, USA)로 분석하였다. 결정된 염기서열 $26 \mathrm{~S}$ rRNA는 GeneBank database로부터 얻은 또 다른 효모의 $26 \mathrm{~S} \mathrm{rRNA}$ 와 비교·분석하였다. $26 \mathrm{~S} \mathrm{rRNA}$ 유사 성 값은 DNAMAN analysis system(Lynnon Biosoft, Quebec, Canada)를 사용하여 alignments, evolutionary distance로부 터 계산하였다. Phylogenetic tree는 neighbour- joining method와 distance matrix data를 사용하여 확인하였다.

\section{향기성분의 추출 및 포집}

쑥 당-추출액의 발효 중 향기성분의 분석을 위한 추출 및 포집방법은 soild phase-micro extraction(SPME)을 이용 한 headspace(Autosampler, HS-7697A, Agilent Co., Waldbronn, Germany) 분석 방법을 사용하였다(17). $5 \mathrm{~mL}$ 를 정확히 취 해 $20 \mathrm{~mL}$ headspace vial에 넣은 후 알루미늄 캡으로 밀봉한 다음 $100 \mu \mathrm{m}$ polydimethylsiloxane(PDMS) fiber에 $100 \mathrm{rpm}$, $100^{\circ} \mathrm{C}$ 에서 8 분 동안 흡착하였다.

\section{향기성분의 분리 및 확인}

쑥 당-추출액의 발효 중 향기성분 분석은 Lee 등(17)의 방법을 변형하여 분리 및 동정하였다. 즉, $\mathrm{GC}-\mathrm{MS}(\mathrm{Gas}$ Chromatograph-Mass spectrometer, GC-7890A, MSD-5975C, Agilent Co., Waldbronn, Germany)를 이용하였으며, column 은 $\mathrm{HP}-5 \mathrm{MS}(30 \mathrm{~m} \times 0.25 \mathrm{~mm}, 0.25 \mu \mathrm{m}$ film thickness)를 사용 하였다. Oven의 온도 프로그램은 $40^{\circ} \mathrm{C}$ 에서 3 분간 머물게 한 후 $180^{\circ} \mathrm{C}$ 까지 1 분당 $5^{\circ} \mathrm{C}$ 로 승온 후 3 분간 머물게 하고 다시 $280^{\circ} \mathrm{C}$ 까지 승온시켰다. 시료는 분활 주입법(10:1)을 
사용하여 0.2 분간 주입하였고 운반기체로 헬륨을 사용하였 으며, 유속은 $1 \mathrm{~mL} / \mathrm{min}$ 로 설정하였다. Injector 및 quadrapole의 온도는 각각 $110^{\circ} \mathrm{C}$ 이었고 질량분석은 전자충 격 이온화 $(69.9 \mathrm{eV})$ 방식을 이용하여 scane mode(범위 50-550)로 실시하였다. 얻어진 chromatogram으로부터 각각 의 peak에 대한 질량 spectrum을 확인하였고 이를 GC-MS NIST library와 비교하여 각각의 성분을 확인하였다.

\section{결과 및 고찰}

\section{발효 중 이화학적 특성 변화}

쑥 당-추출액의 120 일 발효 기간 동안 30 일 간격으로 총 5 회 시료를 채취하여 $\mathrm{pH}$, 당도, 환원당 및 알코올 함량 변화는 Table 1 과 같았다. 발효 0 일째 $\mathrm{pH}$ 는 5.24 에서 60 일째 $\mathrm{pH} 4.72$ 로 감소를 보였으며 그 이후 90 일째까지는 변화가 없다가 최종 120 일째는 $\mathrm{pH} 4.78$ 로 약간 증가하였으며, 이에 상응하여 산도는 발효 0 일째 $0.09 \%$ 에서 발효 30 일 $(0.12 \%)$, 발효 60 일 $(0.16 \%)$, 발효 90 일까지 지속적으로 증가하다가 그 이후에는 변화가 없어 최종산도는 $0.18 \%$ (발효 120 일)을 보였다. 당도는 발효 0 일째 각각 $66.0{ }^{\circ} \mathrm{Brix}$ 에서 발효 120 일 째 $69.0{ }^{\circ} \mathrm{Brix}$ 로 거의 변화가 없었으며 환원당은 발효초기 $(0$ 일째) $202.65 \mathrm{~g} / \mathrm{L}$ 에서 발효 30 일째 $(202.67 \mathrm{~g} / \mathrm{L}$ )까지는 변화 가 없었고 발효 60 일째 $303.68 \mathrm{~g} / \mathrm{L}$, 발효 90일째 430.47 $\mathrm{g} / \mathrm{L}$, 발효 120 일째 $555.27 \mathrm{~g} / \mathrm{L}$ 로 지속으로 증가하여 발효종 기에는 약 2.2 배 이상 증가하였다. 알코올은 발효초기 0 일 째에 $1.0 \%$ 였으며 발효 60 일째까지 $5.0 \%$ 로 증가하였다가 90 일째(4.0\%)까지 약간 감소하였으며 이후 120 일째는 60 일째와 동일한 $5.0 \%$ 를 보였다. 효모는 $7.89 \mathrm{CFU} / \mathrm{mL}$ 에서 발효가 진행됨에 따라 생균수가 꾸준히 감소하여 발효 120 일째는 $2.35 \mathrm{CFU} / \mathrm{mL}$ 수준을 보였다.

전형적인 미생물 발효에서 $\mathrm{pH}$ 감소는 발효 미생물의 생 육에 의해서 감소되며 $\mathrm{pH}$ 감소에 따라 산도는 증가하는 것으로 알려져 있다. 또한 당도의 경우 발효가 진행됨에 따라 감소하며 특히, 효모의 성장에 의해 당도 감소에 따라
알코올이 생성되는 것으로 알려져 있다(18,19). Kim 등(20) 및 Kim 등(21)은 산야채 등의 식물자원 당-추출물을 상온에 서 180 일간 발효 중 $\mathrm{pH}$ 는 감소한다고 보고하여 본 연구 결과와 동일하였으나, 당도는 발효 기간에 따라 다소 낮아 진다고 보고하여 본 연구 결과와는 약간 상이하였다. 이는 원료 및 발효 기간의 차이에 기인한 것으로 판단되었다. 그러나 본 연구의 쑥 당-추출액은 높은 당 함량에 기인하여 발효 중 가용성 고형분( ${ }^{\circ}$ Brix) 변화는 크게 나타나지 않았고 환원당은 발효 중 비환원당인 sucrose는 glucose와 fructose 로 전화되었으며, 발효 중 효모의 작용으로 alcohol 함량은 증가한 것으로 판단되었다. $\mathrm{Kim}$ 등(20) 및 $\mathrm{Kim}$ 등(21)은 이전에 채소 및 산야채 추출물 발효액 중의 생균수를 조사 한 결과 발효기간이 증가함에 따라 감소하는 것으로 보고하 여 본 연구결과와 동일한 결과를 보였다. 이는 발효 기간이 경과함에 따라 삼투압이 높아져 미생물의 생육이 억제되었 거나 이들에 함유되어 있는 항균물질이 용출되었기 때문인 것으로 추정되었으며 특히, 쑥의 경우에는 자체 내에 항균 작용이 있는 것으로 알려져 있어(22) 생균수의 감소에 영향 을 미친 것으로 판단하였다.

\section{발효 중 유리당 및 유기산 함량 변화}

쑥 당-추출액의 120 일 발효 중 $0,30,60,90$, 및 120 일째 총 5 회 시료를 채취하여 유리당 및 유기산 함량 변화를 관찰한 결과 Table 2 와 같았다. 유리당 중 sucrose는 발효 0 일째에 $763.56 \mathrm{~g} / \mathrm{L}$ 에서 발효 60 일째 $717.34 \mathrm{~g} / \mathrm{L}$ 로 서서히 감소하였으며 이후에 급속도로 감소하여 발효 120 일째 $557.77 \mathrm{~g} / \mathrm{L}$ 를 나타내었다. 이와 반대로 glucose와 fructose는 발효 0 일째 각각 $97.53 \mathrm{~g} / \mathrm{L}$ 과 $64.57 \mathrm{~g} / \mathrm{L}$ 에서 발효 120 일째에 는 각각 $262.08 \mathrm{~g} / \mathrm{L}$ 과 $177.69 \mathrm{~g} / \mathrm{L}$ 로 발효초기보다 약 2 배 이상 증가하는 경향을 보였다(Table 2). 이는 Table 1 의 환원 당 변화와 동일한 결과로서 비환원당인 sucrose 함량은 감 소하고 환원당인 glucose 및 fructose의 증가는 미생물이 분비하는 invertase 효소에 기인한 것으로 판단되었다.

Okada 등(12) 이전에 식물추출발효음료의 주요 유리당 은 glucose $(550 \mathrm{~g} / \mathrm{L})$ 와 fructose $(590 \mathrm{~g} / \mathrm{L})$ 로 보고하였으며,

Table 1. Changes of physicochemical properties during the fermentation of mugwort extracts at room temperature for 120 days

\begin{tabular}{|c|c|c|c|c|c|}
\hline \multirow{2}{*}{ Contents } & \multicolumn{5}{|c|}{ Fermentation period (day) } \\
\hline & 0 & 30 & 60 & 90 & 120 \\
\hline $\mathrm{pH}$ & $5.24 \pm 0.26^{\mathrm{al})}$ & $4.74 \pm 0.24^{b}$ & $4.72 \pm 0.24^{b}$ & $4.72 \pm 0.24^{b}$ & $4.78 \pm 0.24^{b}$ \\
\hline Acidity (\%, as lactic acid) & $0.09 \pm 0.01^{b}$ & $0.12 \pm 0.01^{\mathrm{ab}}$ & $0.16 \pm 0.01^{\mathrm{a}}$ & $0.18 \pm 0.01^{\mathrm{a}}$ & $0.18 \pm 0.01^{\mathrm{a}}$ \\
\hline${ }^{\circ}$ Brix & $66.0 \pm 3.36^{\mathrm{a}}$ & $64.0 \pm 3.20^{\mathrm{a}}$ & $68.0 \pm 3.40^{\mathrm{a}}$ & $68.0 \pm 3.40^{\mathrm{a}}$ & $69.0 \pm 3.45^{\mathrm{a}}$ \\
\hline Reducing sugar $(\mathrm{g} / \mathrm{L})$ & $202.65 \pm 10.13^{\mathrm{c}}$ & $200.67 \pm 10.03^{c}$ & $303.68 \pm 15.18^{\mathrm{b}}$ & $430.47 \pm 21.52^{\mathrm{ab}}$ & $555.27 \pm 27.76^{\mathrm{a}}$ \\
\hline Alcohol $(\%, \mathrm{v} / \mathrm{v})$ & $1.0 \pm 0.05^{\mathrm{c}}$ & $3.0 \pm 0.15^{b}$ & $5.0 \pm 0.25^{\mathrm{a}}$ & $4.0 \pm 0.20^{\mathrm{a}}$ & $5.0 \pm 0.25^{\mathrm{a}}$ \\
\hline Yeast cells $(\log \mathrm{CFU} / \mathrm{mL})$ & $7.89 \pm 0.40^{\mathrm{a}}$ & $6.98 \pm 0.35^{\mathrm{a}}$ & $5.24 \pm 0.26^{b}$ & $2.78 \pm 0.14^{\mathrm{c}}$ & $2.35 \pm 0.12^{\mathrm{c}}$ \\
\hline
\end{tabular}

${ }^{1)}$ Values indicate the mean's of three replication $(n=3)$. Different superscripts within the row are significantly different at $p<0.05$ by Duncan's multiple range test. 
Table 2. Changes of free sugar and organic acid contents during the fermentation of mugwort extracts at room temperature for 120 days

\begin{tabular}{cccccc}
\hline \multirow{2}{*}{ Contents $(\mathrm{g} / \mathrm{L})$} & \multicolumn{5}{c}{ Fermentation period (day) } \\
\cline { 2 - 6 } Free sugars & 0 & 30 & 60 & 90 \\
Glucose & $97.53 \pm 3.90^{1) \mathrm{d} 2)}$ & $90.78 \pm 3.63^{\mathrm{d}}$ & $145.76 \pm 5.83^{\mathrm{c}}$ & $210.12 \pm 8.41^{\mathrm{b}}$ & $262.08 \pm 10.48^{\mathrm{a}}$ \\
Fructose & $64.57 \pm 2.58^{\mathrm{d}}$ & $58.56 \pm 2.34^{\mathrm{d}}$ & $97.176 \pm 3.89^{\mathrm{c}}$ & $134.73 \pm 5.39^{\mathrm{b}}$ & $177.69 \pm 7.11^{\mathrm{a}}$ \\
Sucrose & $763.56 \pm 30.54^{\mathrm{a}}$ & $750.77 \pm 30.03^{\mathrm{a}}$ & $717.34 \pm 28.69^{\mathrm{a}}$ & $629.71 \pm 25.19^{\mathrm{b}}$ & $557.77 \pm 22.31^{\mathrm{c}}$ \\
Total & $925.66 \pm 37.03^{\mathrm{a}}$ & $900.11 \pm 36.00^{\mathrm{b}}$ & $960.28 \pm 38.41^{\mathrm{ab}}$ & $974.56 \pm 38.98^{\mathrm{a}}$ & $997.54 \pm 39.90^{\mathrm{a}}$ \\
\hline Organic acids & & & & \\
Oxalic & $5.74 \pm 0.22^{\mathrm{b}}$ & $5.78 \pm 0.27^{\mathrm{b}}$ & $5.91 \pm 0.24^{\mathrm{b}}$ & $6.62 \pm 0.27^{\mathrm{a}}$ & $6.40 \pm 0.22^{\mathrm{a}}$ \\
Tartaric & $0.46 \pm 0.02^{\mathrm{c}}$ & $0.52 \pm 0.02^{\mathrm{c}}$ & $0.58 \pm 0.02^{\mathrm{bc}}$ & $0.65 \pm 0.03^{\mathrm{b}}$ & $0.73 \pm 0.03^{\mathrm{a}}$ \\
Malic & $0.62 \pm 0.03^{\mathrm{a}}$ & $0.30 \pm 0.02^{\mathrm{b}}$ & $0.24 \pm 0.01^{\mathrm{c}}$ & $0.23 \pm 0.03^{\mathrm{c}}$ & $0.22 \pm 0.02^{\mathrm{c}}$ \\
Ascorbic & $0.38 \pm 0.04^{\mathrm{a}}$ & $0.40 \pm 0.02^{\mathrm{a}}$ & $0.40 \pm 0.01^{\mathrm{a}}$ & $0.38 \pm 0.02^{\mathrm{a}}$ & $0.40 \pm 0.03^{\mathrm{a}}$ \\
Lactic & $0.93 \pm 0.04^{\mathrm{b}}$ & $1.65 \pm 0.07^{\mathrm{a}}$ & $1.66 \pm 0.08^{\mathrm{a}}$ & $1.67 \pm 0.05^{\mathrm{a}}$ & $1.64 \pm 0.06^{\mathrm{a}}$ \\
Acetic & $0.72 \pm 0.03^{\mathrm{b}}$ & $1.68 \pm 0.09^{\mathrm{a}}$ & $1.70 \pm 0.05^{\mathrm{a}}$ & $1.73 \pm 0.07^{\mathrm{a}}$ & $1.79 \pm 0.08^{\mathrm{a}}$ \\
Cirtic & $0.39 \pm 0.02^{\mathrm{d}}$ & $0.62 \pm 0.03^{\mathrm{c}}$ & $0.83 \pm 0.05^{\mathrm{b}}$ & $0.95 \pm 0.04^{\mathrm{a}}$ & $0.99 \pm 0.04^{\mathrm{a}}$ \\
Succinic & $2.00 \pm 0.10^{\mathrm{a}}$ & $1.93 \pm 0.08^{\mathrm{a}}$ & $2.04 \pm 0.06^{\mathrm{a}}$ & $2.20 \pm 0.09^{\mathrm{a}}$ & $2.10 \pm 0.08^{\mathrm{a}}$ \\
Fumaric & $0.34 \pm 0.03^{\mathrm{a}}$ & $0.33 \pm 0.03^{\mathrm{a}}$ & $0.33 \pm 0.04^{\mathrm{a}}$ & $0.33 \pm 0.02^{\mathrm{a}}$ & $0.33 \pm 0.01^{\mathrm{a}}$ \\
Total & $11.58 \pm 0.48^{\mathrm{c}}$ & $13.21 \pm 0.44^{\mathrm{b}}$ & $13.69 \pm 0.55^{\mathrm{b}}$ & $14.76 \pm 0.59^{\mathrm{a}}$ & $14.60 \pm 0.50^{\mathrm{a}}$ \\
\hline
\end{tabular}

${ }^{1)}$ Values indicate the mean's of three replication $(\mathrm{n}=3)$.

${ }^{2)}$ Different superscripts within the row are significantly different at $\mathrm{p}<0.05$ by Duncan's multiple range test.

또한 이들은 laminaribiose, maltose 및 $\beta$-D-fructopyranoside 등의 올리고당이 소량 존재한다고 보고하였다. 한편 Lee 등(5)은 3년간 발효·숙성시킨 식물추출발효음료의 유리당 은 glucose $(567.83 \mathrm{~g} / \mathrm{L})$ 및 fructose가 검출되었고 sucrose는 전혀 검출이 되지 않았다고 보고하였다. Kim 등(20)은 산야 채 추출물 발효 중 유리당은 glucose와 fructose만이 검출되 었고 거의 변화가 없다고 보고하였는데, 이들은 산야채 추 출 시 흑설탕을 사용하였으며, 흑설탕의 유리당 분석 결과 sucrose가 검출되지 않았다고 하였다. 이들 결과로부터 유 리당 조성과 함량은 설탕의 종류 및 발효 기간에 의존되는 것으로 판단되었다.

쑥 당-추출액 120 일 발효 중 주요 유기산으로는 oxalic acid, succinic acid가 검출되었으며 그 이외에 tartaric acid, malic acid, ascorbic acid, lactic acid, acetic acid, citric acid 및 fumaric acid가 검출되었다. 발효가 진행됨에 따라 oxalic acid는 발효 0 일째 $5.74 \mathrm{~g} / \mathrm{L}$ 에서 발효 90일째 $6.62 \mathrm{~g} / \mathrm{L}$ 로 증가하다가 발효 120 일에 $6.40 \mathrm{~g} / \mathrm{L}$ 로 약간 감소하는 경향을 보였고, succinic acid 역시 발효 0 일째 $2.00 \mathrm{~g} / \mathrm{L}$ 에서 발효 90 일째 $2.20 \mathrm{~g} / \mathrm{L}$ 로 증가한 후 발효 120 일째 $2.10 \mathrm{~g} / \mathrm{L}$ 로 약간 감소하였으나, 발효 기간 동안 큰 차이를 보이지 않았다. 한편 tartaric acid, lactic acid, acetic acid 및 citric acid는 발효가 진행됨에 따라 증가하여 발효초기( 0 일) 각각 0.46 $\mathrm{g} / \mathrm{L}, 0.93 \mathrm{~g} / \mathrm{L}, 0.72 \mathrm{~g} / \mathrm{L}$ 및 $0.39 \mathrm{~g} / \mathrm{L}$ 에서 발효종기(120일) $0.73 \mathrm{~g} / \mathrm{L}, 1.6 \mathrm{~g} / \mathrm{L}, 1.79 \mathrm{~g} / \mathrm{L}$ 및 $0.99 \mathrm{~g} / \mathrm{L}$ 로 증가하였으나, malic acid는 $0.62 \mathrm{~g} / \mathrm{L}$ 에서 $0.22 \mathrm{~g} / \mathrm{L}$ 로 감소하였다. Ascorbic acid 및 fumaric acid는 발효초기 $0.38 \mathrm{~g} / \mathrm{L}$ 및 $0.34 \mathrm{~g} / \mathrm{L}$ 에서 발효종기 각각 $0.40 \mathrm{~g} / \mathrm{L}$ 및 $0.33 \mathrm{~g} / \mathrm{L}$ 로 발효 중 거의 변화가 없었다(Table 2).

$\mathrm{pH}$ 감소 및 산도 증가는 발효 미생물(젖산균 및 효모)에 의해 생성되는 유기산에 의존되는 것으로 알려져 있다 $(18,19)$. Lee 등(5)은 3 년간 발효.숙성시킨 식물추출발효음 료의 주요 유기산으로 tartaric acid, lactic acid, acetic acid 및 citric acid로 보고하였으며, succinic acid는 전혀 검출이 되지 않았다고 보고하여 본 연구와는 조금 상이하였다. 이 와 같은 결과는 발효 및 숙성이 길어짐에 따라 tartaric acid, lactic acid, acetic acid 및 citric acid는 증가하였고 최종 succinic acid는 효모 에너지 대사 작용에 의해 중간산물이 전환되는 것으로 판단되었다.

\section{발효 중 효모 다양성 변화}

쑥 당-추출액의 120 일 발효 중 30 일 간격으로 총 5 회 시료를 채취하여 $30 \%$ 설탕 함유 $\mathrm{PD}$ 액체배지에서 집식하 여 $26 \mathrm{~S}$ rRNA 염기서열을 분석한 결과, 총 13 그룹의 균이 발견되었으며 주요 효모는 Candida lactis-condensi NRRL Y-1515(FMEBY01 group), Saccharomyces cerevisiase D3C 가 있었고 동정된 200 클론 중 각각 111 clones 및 61 clones 이었다. Candida lactis-condensi NRRL Y-1515는 99-100\% 의 상동성을 보였으며 Saccharomyces cerevisiase D3C는 
98-99\%의 상동성을 보였다. 이외에도 Candida lactiscondensi ABT801(2 clones), Candida lactis-condensi NCAIM Y.00688(1 clone), Candida lactis-condensi NCAIM Y.00714(2 clones), Hanseniaspora uvarum 13w76(3 clones), Hanseniaspora uvarum SYH23-1(2 clones), Hyphopichia burtonii 34(6 clones), Saccharomyces cerevisiase IMAU6Y111 (1 clone), Saccharomyces paradoxusa 124(1 clone), Torulaspora delbrueckii ZIM2414(8 clones), Torulaspora delbrueckii MUCL51211(1 clone) 및 Zygosaccharomyces pseudorouxii ATCC42981(1 clone)의 균이 쑥 당-추출발효 액에서 나타났다(Table 3).

쑥 당-추출액의 120 일 발효 중 30 일 간격으로 시료 채취 하여 효모 종 분포의 변화를 살펴본 결과 Table 4 와 같았다. 발효초기(0일)에는 H. uvarum (5 clones, 12.5\%), H. burtonii (6 clones, $15.0 \%), S$ cerevisiase(21 clones, 52.5\%), $S$. paradoxus(1 clone, 2.5\%) 및 T. delbrueckii(7 clones, 17.5\%) 균주가 나타났으나, $S$. cerevisiase가 우점종을 형성하고 있 었다. 발효 30일째 S. cerevisiase가 95.0\%(38 clones)로 절대 우점종이었고 T. delbrueckii가 5.0\%(2 clones)를 차지하였 다. 한편 발효 60일째 $S$. cerevisiase는 7.5\%(3 clones)로 감소 하였고 $Z$ pseudorouxii 및 C. lactis-condensi가 처음으로 출현하여 전자 $2.5 \%$ (1 clone)를 차지하였으나, 후자는 95.0\%(36 clones)로 절대 우점종이었다. 발효 90일 이후에 는 C. lactis-condensi(40 clones, $100 \%$ )만이 분포하였다.

한편 쑥 당-추출액의 120 일 발효 중 $0,30,60,90,120$ 일째 시료를 채취한 시료의 효모 속 변화는 Fig. 1과 같았다. 쑥 당-추출액 발효 중 발효 0 일째부터 120 일째까지 Candida,

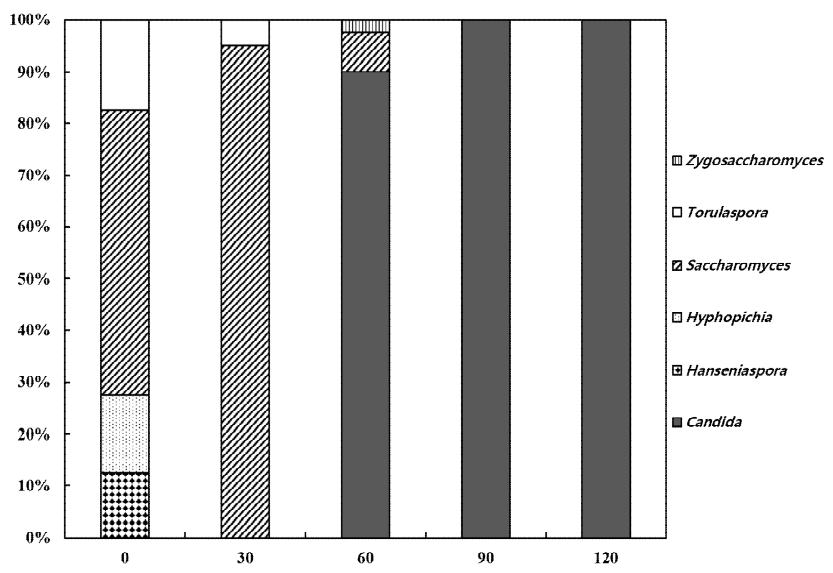

Fig. 1. Population dynamics of dominant species during the fermentation of mugwort extracts at room temperature for 120 days.

Hanseniaspora, Hyphopichia, Saccharomyces, Torulaspora 및 Zygosaccharomyces의 총 6개의 속이 발견되었다. 발효 0일과 30일째는 Saccharomyces 속이 각각 $55.0 \%$ 와 $95.0 \%$ 를 차지하였고 발효 60일 이후부터 Candida 속이 $90.0 \%$ 차지하였고 발효 90 일과 120 일째는 $100 \%$ 를 나타내었다.

이 결과로부터 발효초기(발효 0 및 30일)에는 다양한 효 모 중 특히 Saccharomyces 속의 S. cerevisiase가 쑥 당-추출 액의 발효에 관여하였고, 발효 중기(발효 60일)부터 Candida 속의 C. lactis-condensi가 절대적으로 관여하였다. 와인 및 식초 등의 발효식품에서 C. lactis-condensi는 초기 glucose를 소비시키지 않고 fructose를 완전히 소비하기 때

Table 3. Similarity values of 26S rRNA sequences retrieved from the fermentation of mugwort extract beverage ${ }^{1)}$

\begin{tabular}{ccccc}
\hline Group & No. of clones & Species $^{2}$ & Accession No. ${ }^{3)}$ & Similarity (\%) \\
\hline FMEBY 01 & 111 & Candida lactis-condensi NRRL Y-1515 & U45724 & $99^{4}$-100 \\
FMEBY 02 & 2 & Candida lactis-condensi ABT801 & AJ966518 & 99 \\
FMEBY 03 & 1 & Candida lactis-condensi NCAIM Y.00688 & EF452211 & 99 \\
FMEBY 04 & 2 & Candida lactis-condensi NCAIM Y.00714 & EF452213 & 99 \\
FMEBY 05 & 3 & Hanseniaspora uvarum 13w76 & HQ149311 & 99 \\
FMEBY 06 & 2 & Hanseniaspora uvarum SYH23-1 & EU326137 & 99 \\
FMEBY 07 & 6 & Hyphopichia burtonii 34 & HF952839 & $97-99$ \\
FMEBY 08 & 61 & Saccharomyces cerevisiase D3C & GQ715188 & $98-99$ \\
FMEBY 09 & 1 & Saccharomyces cerevisiase IMAU6Y111 & FN868260 & 99 \\
FMEBY 10 & 1 & Saccharomyces paradoxus a124 & HE660065 & 94 \\
FMEBY 11 & 8 & Torulaspora delbrueckii ZIM 2414 & FN393992 & 99 \\
FMEBY 12 & 1 & Torulaspora delbrueckii MUCL 51211 & AM947681 \\
FMEBY 13 & 1 & Zygosaccharomyces pseudorouxii ATCC 42981 & 99 \\
\hline
\end{tabular}

\footnotetext{
${ }^{1)}$ The $5 \mathrm{~mL}$ of fermented mugwort extract beverage were inoculated into $100 \mathrm{~mL}$ YPD broth with $30 \%$ sucrose and enriched at $30^{\circ} \mathrm{Cfor} 48 \pm 6 \mathrm{~h}$.

${ }^{2}$ Range of $26 \mathrm{~S}$ rDNA gene sequences is similarity values between fermented mugwort extract beverage clones and cultural isolated strain.

${ }^{3)}$ Accession number of the nearest relative. When more than one sequence had the same similarity, only the accession number the first sequence is given.

${ }^{4)}$ Database sequences with $>97 \%$ similarity are shown in bold.
} 
Table 4. Changes of yeast distribution during the fermentation of mugwort extracts at room temperature for 120 days ${ }^{1)}$

\begin{tabular}{|c|c|c|c|c|c|c|}
\hline \multirow{3}{*}{ Species $^{2}$} & \multicolumn{5}{|c|}{ Number of clones $(\mathrm{n} / 40) /$ Percentage $(\%)$} & \multirow{3}{*}{ Number of total clones } \\
\hline & \multicolumn{5}{|c|}{ Fermentation time (day) } & \\
\hline & 0 & 30 & 60 & 90 & 120 & \\
\hline Candida lactis-condensi & & & $36 / 90.0$ & $40 / 100$ & $40 / 100$ & $116 / 58.0$ \\
\hline Hanseniaspora uvarum & $5 / 12.5^{3)}$ & & & & & $5 / 2.5$ \\
\hline Hyphopichia burtonii & $6 / 15.0$ & & & & & $6 / 3.0$ \\
\hline Saccharomyces cerevisiae & $21 / 52.5$ & $38 / 95.0$ & $3 / 7.5$ & & & $62 / 31.0$ \\
\hline Saccharomyces paradoxus & $1 / 2.5$ & & & & & $1 / 0.5$ \\
\hline Torulaspora delbrueckii & $7 / 17.5$ & $2 / 5.0$ & & & & $9 / 4.5$ \\
\hline Zygosaccharomyces pseudorouxii & & & $1 / 2.5$ & & & $1 / 0.5$ \\
\hline Number of total clones & $40 / 100$ & $40 / 100$ & $40 / 100$ & $40 / 100$ & $40 / 100$ & $200 / 100$ \\
\hline
\end{tabular}

\footnotetext{
1) The $5 \mathrm{~mL}$ of the fermented mugwort extract beverage were inoculated into $100 \mathrm{~mL}$ YPD broth with $30 \%$ sucrose and enriched at $30^{\circ} \mathrm{Cfor} 48 \pm 6 \mathrm{~h}$.

${ }^{2}$ Range of $26 \mathrm{~S}$ rDNA gene sequences is similarity values between fermented mugwort extract beverage clones and cultural isolated strain.

${ }^{3)}$ Bold words indicate predominant during the fermentation of mugwort extracts.
}

문에 대표적인 fructophilic 효모 종으로 알려져 있으며, $Z$ pseudorouxii 역시 유사하게 fructophilic 대사 종으로 보고되 어 있다. 그러나 S. cerevisiae 및 Hanseniaspora 속은 대표적 인 glucophilic 대사 종으로(23-26) 발효초기 sucrose가 glucose와 fructose로 전환되고, 이때 $S$. cerevisiae가 초기에 관여하여 glucose를 소비하여 알코올, 유기산 및 탄산가스 등을 생성하는 것으로 판단되었다. 또한, 발효 중기 이후에 는 fructose가 생성됨에 따라 fructose 대사 종인 $C$. lactis-condens가 관여하여 다양한 유기산 등의 이차대사산 물을 생성시키는 것으로 판단되었다. Lee 등(5)은 3 년간 발효·숙성시킨 식물추출발효음료의 우점종으로 C. lactiscondensi와 C. zeylanoides로 보고하여 본 연구결과로 비추 어 보아 발효 60 일 이후에는 C. lactis-condensi 종이 주를 이루는 것으로 판단되었다. 한편 발효초기 $S$. cerevisiae 다 음으로 우점종인 T. delbrueckii는 이전에는 $S$. rosei 혹은 $S$. delbrueckii로 알려진 것으로 종으로 현재에는 $T$. delbrueckii로 재분류된 종으로 포도와 같은 과일표면에 상 제하는 균으로 S. cerevisiae와 동일하게 발효에 작용하나, 와인 등의 발효 시 당으로부터 휘발성산이나 acetaldehyde 생성이 적은 것으로 알려져 있다 $(27,28)$.

\section{발효 중 향기성분 변화}

쑥 당-추출액의 120 일간 발효 중 30 일 간격으로 시료를 채취한 후 GC-MS로 향기성분을 분석하여 발효기간 중 변 화를 살펴본 결과 Table 5 와 같았다. 발효 기간 동안 주 향기성분은 검은 송로버섯의 주요 향기성분으로 알려져 있는 3-methyl-1-butanol로 발효 0일째 65.95\%에서 30일째 까지 증가하여 $82.98 \%$ 를 차지하였고 이후에는 약 $74 \%$ 수 준이었다. 발효초기(0일) 3-methyl-1-butanol 이외에 isobutyl acetate(2.76\%), 1-nonen-3-ol(1.88\%), isopentyl alcohol (5.89\%), benzyl alcohol(1.16\%), phenylethyl alcohol(1.96\%)
및 5-hydroxymethyl-2-furaldehyde(1.32\%)이 상대적으로 높 은 peak 면적을 나타내었다. 발효가 진행됨에 따라 isopentyl alcohol은 급격히 감소하여 발효 120 일째 $0.12 \%$ 를 차지 하였고 benzyl alcohol, phenylethyl alcohol 및 5hydroxymethyl- 2-furaldehyde은 증가하여 각각 $2.56 \%$, $5.48 \%$, 및 $2.54 \%$ 를 나타내었고 1-nonen-3-ol은 발효 30일째 와 60 일째는 검출되지 않았으나, 발효 90 일째와 120 일째는 각각 $3.06 \%$ 와 $3.61 \%$ 를 검출되었고 3-ethoxy-1-butene 및 propylcyclopropane은 발효 0 일째 각각 $0.83 \%$ 및 $0.41 \%$ 에서 발효가 진행됨에 증가하여 120 일째 각각 $3.30 \%$ 및 $1.08 \%$ 를 차지하였다. 한편 발효 60일째 cis-3-hexene-1-ol이 처음 나 타나 $1.95 \%$ 에서 발효종기(120일) $2.68 \%$ 차지하였고 furfural은 발효 90 일째 처음 검출되어 $1.44 \%$ 에서 120 일째 $1.40 \%$ 로 검출되었고, 3,3-dimethyldiaziridine $(4.78 \%)$ 은 발 효 60 일째만 검출되었다. 이외에도 발효초기 검출된 소량 의 향기성분들은 발효가 진행됨에 따라 검출되지 않았고 새로운 소량의 향기성분들이 검출되는 것을 확인할 수 있었 다. 이런 결과는 발효가 진행됨에 따라 미생물상의 변화에 의한 것으로 판단되었다. 발효 전체기간 동안 알코올류가 주요 향기성분이었고 특히, 발효 초기에 알코올류가 주 향 기성분으로 이는 S. cerevisiae의 대사 작용에 의해서 생성된 것으로 판단되며 또한, 발효 60 일째 C. lactis-condensi가 우점함에 따라 furfural, cis-3-hexene-1-ol, butyrolactone 및 5-hydroxymethyl-2-furaldehyde 등이 검출되어 이들의 향기 성분은 C. lactis-condensi의 대사 작용과 관련이 깊은 것으 로 판단되었다. 알코올류의 향기성분 중 phenylethyl alcohol 및 benzyl alcohol는 효모발효에서 중요한 대사산물로서, phenylethyl alcohol은 전형적인 장미와 유사한 향을 가지고 있으며, benzyl alcohol은 꽃과 유사한 향을 가지고 있다 $(29,30)$. 본 연구에서는 발효가 진행됨에 따라 phenylethyl alcohol 및 benzyl alcohol 증가하는 경향을 보였다. 
Table 5. Changes of volatile compounds during the fermentation of mugwort extracts at room temperature for 120 days

\begin{tabular}{|c|c|c|c|c|c|c|c|}
\hline \multirow{2}{*}{ No } & \multirow{2}{*}{ Volatile compounds } & \multirow{2}{*}{ R.T. ${ }^{1)}(\min )$} & \multicolumn{5}{|c|}{ Fermentation period (day) / Area\% $\%^{2)}$} \\
\hline & & & 0 & 30 & 60 & 90 & 120 \\
\hline 1 & 2-Mercaptoethanol & 3.361 & & $0.03 \pm 0.00^{\mathrm{a}}$ & & & \\
\hline 2 & Formohydrazide & 3.653 & & & & & $0.15 \pm 0.01^{\mathrm{a}}$ \\
\hline 3 & Thiirane & 3.756 & & & $0.29 \pm 0.01^{\mathrm{a}}$ & & \\
\hline 4 & Ethyl propanoate & 3.762 & & $3.31 \pm 0.13$ & & & \\
\hline 5 & 3-Methyl-1-butanol & 4.294 & $65.95 \pm 2.64^{\mathrm{b}}$ & $82.98 \pm 3.32^{\mathrm{a}}$ & $74.25 \pm 2.97^{\mathrm{ab}}$ & $74.31 \pm 2.97^{\mathrm{ab}}$ & $73.82 \pm 2.95^{\mathrm{ab}}$ \\
\hline 6 & Isobutanol & 5.021 & & & & $0.09 \pm 0.01^{\mathrm{a}}$ & $0.11 \pm 0.02^{\mathrm{a}}$ \\
\hline 7 & 2-Fluoropropene & 5.233 & & & & $0.06 \pm 0.00^{\mathrm{a}}$ & $0.07 \pm 0.02^{\mathrm{a}}$ \\
\hline 8 & Glycolic acid & 5.290 & & & $0.04 \pm 0.00^{\mathrm{a}}$ & & \\
\hline 9 & Isobutyl acetate & 5.381 & $2.76 \pm 0.11^{\mathrm{a}}$ & & & & \\
\hline 10 & Propanamide & 5.410 & & $0.28 \pm 0.01^{\mathrm{a}}$ & & & \\
\hline 11 & Propanenitrile & 5.816 & & $0.01 \pm 0.00^{\mathrm{a}}$ & & & \\
\hline 12 & Acetic acid & 6.039 & & & $0.09 \pm 0.00^{\mathrm{a}}$ & $0.03 \pm 0.00^{b}$ & \\
\hline 13 & Ethylvinyl sulfide & 6.280 & $0.09 \pm 0.00^{\mathrm{a}}$ & & & & \\
\hline 14 & 3-Hydroxytetrahydrofuran & 6.291 & & $0.05 \pm 0.00^{\mathrm{a}}$ & & & \\
\hline 15 & 1,2 Dimethyl hydrazine & 6.371 & & & & $0.03 \pm 0.00$ & $0.06 \pm 0.00$ \\
\hline 16 & Bis(2-butoxyethyl) ether & 6.646 & & $1.53 \pm 0.06^{\mathrm{a}}$ & & & \\
\hline 17 & 1-Nonen-3-ol & 6.692 & $1.88 \pm 0.08^{\mathrm{c}}$ & & & $3.06 \pm 0.12^{b}$ & $3.61 \pm 0.14^{\mathrm{a}}$ \\
\hline 19 & 3-Ethoxy-1-butene & 6.943 & $0.83 \pm 0.03^{\mathrm{c}}$ & $2.63 \pm 0.09^{\mathrm{b}}$ & $2.90 \pm 0.12^{\mathrm{a}}$ & $2.63 \pm 0.11^{\mathrm{b}}$ & $3.03 \pm 0.15^{\mathrm{a}}$ \\
\hline 20 & 3,3-Dimethyldiaziridine & 7.178 & & & $4.78 \pm 0.19^{\mathrm{a}}$ & & \\
\hline 21 & Furfural & 7.333 & & & & $1.44 \pm 0.06^{\mathrm{a}}$ & $1.40 \pm 0.04^{\mathrm{a}}$ \\
\hline 22 & 1-Silacyclo-2,4-hexadiene & 7.355 & $0.20 \pm 0.01^{\mathrm{a}}$ & $0.15 \pm 0.02^{b}$ & & & \\
\hline 23 & 2-Butene & 7.579 & $0.02 \pm 0.00^{\mathrm{a}}$ & & & & \\
\hline 24 & Urea & 7.750 & & & $0.09 \pm 0.19^{\mathrm{a}}$ & & \\
\hline 25 & 2-Propenal & 7.813 & $0.06 \pm 0.00^{\mathrm{a}}$ & $0.08 \pm 0.01^{\mathrm{a}}$ & & $0.07 \pm 0.00$ & $0.08 \pm 0.00$ \\
\hline 26 & cis-3-Hexene-1-ol & 8.139 & & & $1.95 \pm 0.05^{\mathrm{b}}$ & $2.34 \pm 0.09 \mathrm{a}^{\mathrm{b}}$ & $2.68 \pm 0.11^{\mathrm{a}}$ \\
\hline 27 & trans,trans-2,4-Hexadiene & 8.145 & $0.53 \pm 0.02^{\mathrm{b}}$ & $0.65 \pm 0.03^{\mathrm{a}}$ & & & \\
\hline 28 & 3-Ethoxypropanol & 8.397 & & $0.10 \pm 0.00^{\mathrm{a}}$ & & & \\
\hline 29 & Propylcyclopropane & 8.614 & $0.41 \pm 0.02^{\mathrm{c}}$ & $0.33 \pm 0.01^{\mathrm{c}}$ & $0.88 \pm 0.06^{b}$ & $0.98 \pm 0.09^{\mathrm{a}}$ & $1.08 \pm 0.10^{\mathrm{a}}$ \\
\hline 30 & Isopentyl alcohol & 8.872 & $5.89 \pm 0.24^{\mathrm{a}}$ & $0.37 \pm 0.02^{b}$ & $0.12 \pm 0.01^{\mathrm{c}}$ & $0.13 \pm 0.01^{\mathrm{c}}$ & $0.12 \pm 0.00^{c}$ \\
\hline 31 & Cyclohexane & 9.393 & & & $0.05 \pm 0.00^{\mathrm{a}}$ & $0.02 \pm 0.00^{\mathrm{a}}$ & \\
\hline 32 & N-Methyleneethenamine & 9.410 & & & & & $0.02 \pm 0.00^{\mathrm{a}}$ \\
\hline 33 & (2-Methyl-1-propenyl)hydrazine & 10.491 & $0.04 \pm 0.00^{\mathrm{a}}$ & & & & \\
\hline 34 & Tetrahydropyran & 10.497 & & $0.01 \pm 0.00^{\mathrm{a}}$ & & & \\
\hline 35 & Butyrolactone & 10.571 & & & $0.20 \pm 0.02^{\mathrm{a}}$ & $0.16 \pm 0.01^{b}$ & $0.15 \pm 0.01^{b}$ \\
\hline 36 & Benzaldehyde & 11.487 & & & & $1.14 \pm 0.03^{\mathrm{a}}$ & $1.13 \pm 0.05^{\mathrm{a}}$ \\
\hline 37 & Benzoyl isothiocyanate & 11.504 & $0.04 \pm 0.00^{\mathrm{a}}$ & & & & \\
\hline 38 & 2-Formyl-5-methylfuran & 11.653 & & & $1.10 \pm 0.08^{\mathrm{a}}$ & $0.57 \pm 0.02^{\mathrm{b}}$ & $0.49 \pm 0.02^{b}$ \\
\hline 39 & 2,3-Dihydro-1H-imidazo[1,2-b]pyrazole & 11.675 & $0.07 \pm 0.00^{\mathrm{a}}$ & $0.04 \pm 0.00^{b}$ & & & \\
\hline 40 & 2-Buten-1-ol & 12.162 & $0.05 \pm 0.00^{b}$ & $0.02 \pm 0.00^{b}$ & $0.17 \pm 0.01^{\mathrm{a}}$ & $0.16 \pm 0.02^{\mathrm{a}}$ & $0.18 \pm 0.02^{\mathrm{a}}$ \\
\hline 41 & 1,3-Dithiolane & 12.374 & & $0.01 \pm 0.00^{\mathrm{a}}$ & & & \\
\hline 42 & 2,2-Dimethyl-3-octanol & 12.660 & $0.11 \pm 0.01^{\mathrm{a}}$ & & & & \\
\hline 43 & 6-Nonynoic acid & 12.712 & & & & $0.27 \pm 0.01^{\mathrm{a}}$ & \\
\hline
\end{tabular}




\begin{tabular}{|c|c|c|c|c|c|c|c|}
\hline \multirow{2}{*}{ No } & \multirow{2}{*}{ Volatile compounds } & \multirow{2}{*}{ R.T. ${ }^{1)}(\min )$} & \multicolumn{5}{|c|}{ Fermentation period (day) / Area $\%^{2)}$} \\
\hline & & & 0 & 30 & 60 & 90 & 120 \\
\hline 44 & 7-Chlorohept-2-yne & 12.791 & & $0.34 \pm 0.02^{\mathrm{a}}$ & & & \\
\hline 45 & $\beta$-trans-Ocimene & 12.789 & & & $0.26 \pm 0.01^{\mathrm{a}}$ & & $0.30 \pm 0.03^{\mathrm{a}}$ \\
\hline 46 & Benzyl alcohol & 13.798 & $1.16 \pm 0.05^{\mathrm{b}}$ & $0.93 \pm 0.04^{\mathrm{b}}$ & $2.90 \pm 0.12^{\mathrm{a}}$ & $2.75 \pm 0.11^{\mathrm{a}}$ & $2.56 \pm 0.10^{\mathrm{a}}$ \\
\hline 48 & 2,3-Dihydro-1-benzothiophene & 14.525 & & $0.01 \pm 0.00^{\mathrm{a}}$ & & & \\
\hline 49 & 2-(2-Methylvinyl)thiophene & 15.109 & & & & $0.02 \pm 0.00^{\mathrm{a}}$ & $0.03 \pm 0.01^{\mathrm{a}}$ \\
\hline 50 & 2-Propenamide & 15.607 & $0.02 \pm 0.00^{\mathrm{a}}$ & & & $0.03 \pm 0.00^{\mathrm{a}}$ & $0.04 \pm 0.02^{\mathrm{a}}$ \\
\hline 51 & Phenylethyl alcohol & 15.984 & $1.96 \pm 0.08^{\mathrm{c}}$ & $4.28 \pm 0.17^{\mathrm{b}}$ & $6.01 \pm 0.24^{\mathrm{a}}$ & $5.76 \pm 0.23^{\mathrm{a}}$ & $5.48 \pm 0.22^{\mathrm{a}}$ \\
\hline 52 & 2-(Methylthio)ethylamine & 16.677 & & & & $0.02 \pm 0.00^{\mathrm{a}}$ & \\
\hline 53 & Diaminomaleonitrile & 16.825 & $0.09 \pm 0.00$ & $0.04 \pm 0.00^{\mathrm{a}}$ & $0.04 \pm 0.00^{\mathrm{a}}$ & $0.04 \pm 0.00^{\mathrm{a}}$ & $0.05 \pm 0.00^{\mathrm{a}}$ \\
\hline 54 & 1-(2-Thienyl)-1-propanone & 17.117 & & & $0.39 \pm 0.02^{\mathrm{a}}$ & & \\
\hline 55 & $\mathrm{~N}$-(2-Propynyl)aziridine & 17.123 & & & & $0.27 \pm 0.01$ & $0.22 \pm 0.01$ \\
\hline 56 & 5,5-Dimethyl-1,3-hexadiene & 17.358 & $0.12 \pm 0.05^{\mathrm{b}}$ & & $0.24 \pm 0.01^{\mathrm{a}}$ & & \\
\hline 57 & 2,3,3-Trimethyl-1,4-pentadiene & 17.361 & & $0.07 \pm 0.00^{b}$ & & $0.27 \pm 0.01^{\mathrm{a}}$ & $0.27 \pm 0.01^{\mathrm{a}}$ \\
\hline 58 & 3,5-Dimethylcyclohexene & 17.363 & & & & & \\
\hline 59 & Benzyl azide & 17.661 & $0.01 \pm 0.00^{b}$ & $0.01 \pm 0.00^{\mathrm{b}}$ & $0.03 \pm 0.00^{\mathrm{a}}$ & & \\
\hline 60 & 2,1-Benzisoxazole & 17.655 & & & & $0.04 \pm 0.00^{\mathrm{a}}$ & $0.05 \pm 0.00^{\mathrm{a}}$ \\
\hline 61 & Ethyl caproate & 18.118 & & $0.08 \pm 0.02^{\mathrm{a}}$ & $0.10 \pm 0.02^{\mathrm{a}}$ & $0.10 \pm 0.03^{\mathrm{a}}$ & $0.10 \pm 0.01^{\mathrm{a}}$ \\
\hline 62 & 5-Hydroxymethyl-2-furaldehyde & 18.845 & $1.32 \pm 0.05^{\mathrm{b}}$ & $1.07 \pm 0.04^{b}$ & $2.75 \pm 0.11^{\mathrm{a}}$ & $2.74 \pm 0.11^{\mathrm{a}}$ & $2.54 \pm 0.10^{\mathrm{a}}$ \\
\hline 63 & Tetracyclo $[3 \cdot 2 \cdot 0.0(2,7) \cdot 0(4,6)]$ heptane & 19.303 & & $0.02 \pm 0.00^{\mathrm{a}}$ & & & \\
\hline 64 & 2-Propenoic acid-2-phenylethyl ester & 19.589 & $0.12 \pm 0.04^{\mathrm{a}}$ & $0.07 \pm 0.02^{\mathrm{b}}$ & & & \\
\hline 65 & 3-(4-Methylphenyl)-1-propanol & 20.916 & $0.01 \pm 0.00^{\mathrm{a}}$ & & & & \\
\hline 66 & 2,3,4,5-Tetrahydropyridazine & 22.324 & $0.01 \pm 0.00^{\mathrm{a}}$ & & $0.02 \pm 0.00^{\mathrm{a}}$ & & \\
\hline 67 & 2-Methylthietane & 22.689 & & & $0.03 \pm 0.00^{\mathrm{a}}$ & & \\
\hline 68 & trans-2-Butene episulfide & 22.693 & & & & $0.03 \pm 0.00^{\mathrm{a}}$ & \\
\hline 69 & a-Ethyl-1-cyclohexaneacetic acid & 22.696 & & & & & $0.02 \pm 0.00^{\mathrm{a}}$ \\
\hline 70 & Ethyl caprate & 22.699 & & $0.05 \pm 0.01^{\mathrm{a}}$ & & & \\
\hline 71 & (+)-Camphor-10-sulfonyl chloride & 23.154 & & & & $0.29 \pm 0.05^{\mathrm{a}}$ & \\
\hline 72 & 2-Methylpropanoic acid & 27.045 & & & & $0.02 \pm 0.00^{\mathrm{a}}$ & $0.02 \pm 0.00^{\mathrm{a}}$ \\
\hline 73 & 1,2-Dimethoxy-ethane & 27.051 & & & $0.03 \pm 0.01^{\mathrm{a}}$ & & \\
\hline 74 & Ethyl undecanoate & 27.055 & $0.13 \pm 0.03^{\mathrm{a}}$ & & & & \\
\hline 75 & 4-Hydroxy-2-butanone & 32.870 & & $0.02 \pm 0.00^{\mathrm{a}}$ & & & \\
\hline 76 & 3-Hydroxy-2-butanone & 36.103 & $0.02 \pm 0.00^{\mathrm{a}}$ & & & & \\
\hline 77 & Arachidic acid ethyl ester & 36.108 & & $0.02 \pm 0.00^{\mathrm{a}}$ & $0.20 \pm 0.01^{\mathrm{a}}$ & $0.10 \pm 0.01^{\mathrm{a}}$ & $0.10 \pm 0.00^{\mathrm{a}}$ \\
\hline 78 & 2-Pentyn-1-ol & 38.804 & & & $0.05 \pm 0.02^{\mathrm{a}}$ & & \\
\hline 79 & Methyl 13-octadecenoate & 38.809 & & $0.35 \pm 0.05^{\mathrm{a}}$ & & & \\
\hline 80 & 2-Methylaziridine & 39.135 & & $0.02 \pm 0.00^{b}$ & $0.04 \pm 0.01^{\mathrm{a}}$ & & \\
\hline 81 & 2,2,4-Trimethyl-1,3-pentanediol & 39.141 & & & & & $0.04 \pm 0.00^{\mathrm{a}}$ \\
\hline
\end{tabular}

${ }^{1)}$ R.T., Retention time.

${ }^{2)}$ Values indicate the mean's of three replication $(n=3)$. Different superscripts within the row are significantly different at $p<0.05$ by Duncan's multiple range test.

이상의 결과에서 발효 중 $\mathrm{pH}$ 는 감소하고 총산, 환원당 및 알코올 함량은 증가하였으나, 당도는 거의 변화가 없었 다. 한편 비환원당은 sucrose 함량은 감소하였고 glucose와 fructose 함량은 증가하였다. 주요 유기산으로는 oxalic acid 및 succinic acid였고 oxalic acid는 증가하였고 succinic acid 는 거의 변화가 없었다. 효모 다양성을 조사한 결과 $C$. 
lactis-condensi, $H$. uvarum, $H$. burtonii, $S$. cerevisiae, $S$. paradoxus, T. delbrueckii 및 $Z$ pseudorouxii 7종의 효모가 관찰되었고 S. cerevisiae는 발효 30일째 $95.0 \%$ 로 증가하여 이후 감소하여 발효종기에 나타나지 않았고 C. lactiscondensi는 60 일째 처음 나타나 발효 90 일째 이후 $100 \%$ 를 차지하였다. 이에 따라 발효 중 주 향기성분은 3-methyl-1butanol 이었고 또한, isopentyl alcohol은 발효가 진행됨에 따라 감소하였고, benzyl alcohol, phenylethyl alcohol 및 5-hydroxymethyl-2-furancarboxaldehyde는 증가하는 경향 을 보였다. 이로부터 발효초기에는 S. cerevisiae가 관여하 나 발효 중기 이후부터는 C. lactis-condensi가 작용하는 것 으로 판단되었고, 이에 따라 발효 중 향기성분의 변화가 이루어지는 것으로 판단되었다. 앞으로 효모균주의 분리와 각각의 균 접종에 따른 향기성분 등의 분석을 통하여 식물 추출발효음료의 효모 종과 향기성분과의 상관성 분석이 더 이루어져야 할 것으로 판단되었다.

\section{요 약}

식물추출발효음료는 다양한 과채류, 약초류 및 해조류 등을 혼합하여 당 추출하여 자연 발효시키는 것이다. 본 연구에서는 쑥 당-추출액의 발효 중 이화학적 특성, 효모 다양성 및 향기성분을 연구하였다. 쑥 당-추출액의 발효 중 $\mathrm{pH}$ 는 발효 0 일째 5.24 에서 120 일째 4.78 로 감소하였고 산도 및 환원당은 각각 $0.09 \%$ 및 $202.65 \mathrm{~g} / \mathrm{L}$ 에서 $0.18 \%$ 및 $555.27 \mathrm{~g} / \mathrm{L}$ 로 증가하였고 알코올 함량은 발효 종기에 $5.0 \%$ 를 나타내었다. Sucrose 함량은 $763.56 \mathrm{~g} / \mathrm{L}(0$ 일 $)$ 에서 $557.77 \mathrm{~g} / \mathrm{L}(120$ 일)로 감소하였고 glucose와 fructose는 각각 $97.53 \mathrm{~g} / \mathrm{L}$ 과 $64.57 \mathrm{~g} / \mathrm{L}$ 에서 $262.08 \mathrm{~g} / \mathrm{L}$ 와 $177.69 \mathrm{~g} / \mathrm{L}$ 로 증가 하였다. 한편 주요 유기산으로는 oxalic acid 및 succinic $\mathrm{acid}$ 가 존재하였다. 효모는 $7.89 \mathrm{CFU} / \mathrm{mL}$ 에서 $2.35 \mathrm{CFU} / \mathrm{mL}$ 로 감소하였다. $26 \mathrm{~S} \mathrm{rRNA}$ 를 기초로 하여 분석한 결과, Saccharomyces cerevisiae는 발효 30일째 $95.0 \%$ 로 가장 높 았고 60 일째는 감소하여 $7.5 \%$ 였으며, Candida lactis-condensi 는 60 일째 $(90 \%)$ 처음 출현하여 발효 90 일째 $100 \%$ 까지 증 가하였다. 향기성분은 3-methyl-1-butanol로 발효 0일째 $65.95 \%$ 에서 30 일째까지 증가하여 $82.98 \%$ 를 차지하였고 이후에는 약 $74.0 \%$ 수준이었다. 한편 benzyl alcohol, phenylethyl alcohol 및 5-(hydroxymethyl)-2-furancarboxaldehyde 은 증가하여 각각 $2.56 \%, 5.48 \%$ 및 $2.54 \%$ 를 나타내었다.

\section{감사의 말}

본 연구는 농림축산식품부의 농림식품기술기획평가원 고부가가치식품기술개발사업(과제번호: 116009-03) 및 농
생명산업기술개발사업(과제번호: 314021-03)의 지원에 의 해 이루어진 것입니다.

\section{References}

1. Lee SD, Park HH, Kim DW, Bang BH (2000) Bioactive constituents and utilities of Artemisia sp. as medicinal herd and foodstuff. Korean J Food Nutr, 13, 490-505

2. Seo KS, Yun KW (2011) Antimicrobial activity and total polyphenol content of extracts from Artemisia capillaris Thunb. and Artemisia iwayomogi Kitam. used as injin. Korean J Plant Res, 24, 10-16

3. Choi BB, Lee HJ, Bang SK (2004) Studies on the amino acid, sugar analysis and antioxidative effect of extracts from Artemisia sp.. Korean J Food Nutr, 17, 86-91

4. Choi BB, Lee HJ, Bang SK (2005) Studies on the volatile flavor components biochemical characterizations of Artemisia princeps and $A$ argyi. Korean J Food Nutr, $18,334-340$

5. Lee CK, Kim B, Kang YM, Lee HY, Hwang CE, Ahn MJ, Seo WT, Cho KM (2014) Microbial diversity in the enrichment cultures from the fermented beverage of plant extract ribosomal RNA sequence analysis. Korean $\mathbf{J}$ Microbiol, 50, 351-359

6. Giraffa G, Neviani E (2001) DNA-based, cultureindependent strategies for evaluating microbial communities in food-associated ecosystems. Int J Food Microbiol, 67, 19-34

7. Haque MA, Seo WT, Hwang CE, Lee HY, Ahn MJ, Cho KM (2015) Culture-independent analysis of yeast diversity in Korean traditional fermented soybean foods (Doenjang and Kanjang) based on 26S rRNA sequence. J Korean Soc Appl Biol Chem, 58, 377-385

8. Kim ML, Choi MA, Jeong JS (2008) Development of fermented beverage using the sea tangle extract, and quality characteristics thereof. Korean J Food Preserv, 15, 21-29

9. Blandino A, Al-Aseeri ME, Pandiella SS, Cantero D, Webb C (2003) Cereal-based fermented foods and beverages. Food Res Int, 36, 527-543

10. Cho EK, Cho HE, Cho YJ (2010) Inhibitory effects of angiotensin converting enzyme and a-glucosidase, and alcohol metabolizing activity of fermented Omija (Schizandra Chinensis Baillon) beverage. J Korean Soc Food Sci Nutr, 39, 655-661

11. Cho YJ, Park SY, Lee EJ, Lee CH (2001) Effective 
components of commercial fermented plant extracts and their HACCP scheme. Food Eng Prog, 5, 165-174

12. Okada H, Fukushi E, Yamamori A, Kawazoe N, Onodera S, Kawabata J, Shiomi N (2006) Structural analysis of a novel saccharide isolated from fermented beverage of plant extract. Carbohydr Res, 341, 925-929

13. Miller GL (1959) Use of dinitrosalicylic acid reagent for determination of reducing sugar. Anal Chem, 31, 426-428

14. Cho KM, Hwang CE, Kim SC, Joo OS (2018) Physicochemical properties, phytochemicals, and biological activities of heat-treated Elaeagnus multiflora juice and vinegar. Korean J Food Preserv, 25, 52-61

15. Hwang CE, Lee DH, Joo OS, Lee HY, Kim SC, Park KS, Um BS, Cho KM (2017) Comparison of physicochemical property, phytochemical contents, and biological activity of soy sauce added with bitter melon powder. Korean J Food Preserv, 24, 1138-1148

16. Joo OS, Kang ST, Jeong CH, Lim JW, Park YG, Cho KM (2011) Manufacturing of the enhances antioxidative wine using a ripe Daebong persimmon (Dispyros kaki L). J Appl Biol Chem, 54, 126-134

17. Lee HY, Seo WT, Jeong SH, Hwang CE, Ahn MJ, Lee AR, Shin JH, Lee JY, Jo HK, Cho KM (2016) Physiochemical characteristics and volatile flavor compounds of produced mixture wine with kiwi and permission fruits using wild yeast, Saccharomyces cerevisiae Y28. Korean J Microbiol, 52, 98-109

18. Seo WT, Kim HG, Lee JS, Cho KM (2011) Making of Dongchimi naengmyeun broth which has enhanced antioxidant activity using purple sweet potato. Korean J Microbiol, 47, 143-150

19. Cho HK, Lee JY, Seo WT, Kim MK, Cho KM (2012) Quality characteristics and antioxidant effects during Makgeolli fermentation by purple sweet potato-rice Nuruk Korean J Food Sci Technol, 44, 728-735

20. Kim NM, Lee JW, Do JH, Yang JW (2003) Effects of the fermentation periods on the qualities and functionalities of the fermentation broth wild vegetables. Korean J Food Sci Technol, 35, 272-279
21. Kim NM, Lee JW, Do JH, Park CK, Yang JW (2005) Effects of the fermentation periods on the qualities and functionality of the vegetable fermentation broths. Korean J Med Crop Sci, 13, 293-299

22. Kim YS, Kim MN, Kim JO, Lee JH (1994) The effect of hot water-extract and flavor compounds of mugwort on microbial growth. J Korean Soc Food Nutr, 23, 994-1000

23. Ciani M, Fatichenti F (1999) Selective sugar consumption by apiculate yeasts. Lett Appl Microbiol, 28, 203-206

24. Granchi L, Ganucci D, Messini A, Vincenzini M (2002) Oenological properties of Hanseniaspota osmophila and Kloeckera coricis from wines produced by spontaneous fermentations of normal and dried grapes. FEMS Yeast Res, 2, 403-407

25. Hong YA, Park HD (2013) Role of non-Saccharomyces yeast in Korean wines produced from Campbell early grape: potential use of Hanseniaspora uvarum as a starter culture. Food Microbiol, 34, 207-214

26. Solieri L, Giudici P (2008) Yeasts associated to traditional balsamic vinegar: Ecological and technological features. Int J Food Microbiol, 125, 36-45

27. Renault P, Miot-Sertier C, Marullo P, Hernandez-Orte P, Lagarrigue L, Lonvaud-Funel A, Bely M (2009) Genetic characterization and phenotypic variability in Torulaspora delbrueckii species: Potential applications in the wine industry. Int J Food Microbiol, 134, 201-210

28. van Breda V, Jolly N, van Wyk J (2013) Characterisation of commercial and natural Torulaspora delbrueckii wine yeast strains. Int J Food Microbiol, 163, 80-88

29. Ledauphin J, Guichard H, Saint-Clair J, Picoche B, Barillier D (2003) Chemical and sensorial aroma characterization of freshly distilled Clavados. 2. Identification of volatile compounds and Key odorants. J Agric Food Chem, 51, 433-542

30. Sun SY, Jiang WG, Zhao YP (2011) Evaluation of different Saccharomyces cereviae strains on the profile of volatile compounds and polyphenols in cherry wines. Food Chem, 127, 547-555 